\title{
ORGANIC FARMING TECHNOLOGY OF UTILIZING OIL PALM EMPTY FRUIT BUNCH COMPOST AND LEGUMINOSAE PLANT COMPOST TO REDUCE NPK FERTILIZER DOSAGE ON GROWTH AND YIELD OF BROWN RICE (ORYZA NIVARA)
}

\author{
Fitriana Maria*, Sulaiman Firdaus, Sodikin Erizal \\ Department of Agronomy, Faculty of Agriculture, Sriwijaya University, Indonesia \\ *E-mail: mariafitriana56@yahoo.com
}

\begin{abstract}
This research was aimed to evaluate the effect of organic and inorganic fertilizer combinations on growth and yield of brown rice (Oryza nivara L). The research was conducted from July to November 2018 in experimental farm of Faculty of Agriculture, Sriwijaya University. The method used in this research was randomized block design with seven treatments and three replications. Treatments given were 100\% urea fertilizer, SP-36, $\mathrm{KCl}\left(\mathrm{P}_{1}\right)$; stringbean compost $+25 \%$ urea, SP-36, $\mathrm{KCl}\left(\mathrm{P}_{2}\right)$; stringbean compost $+50 \%$ urea, SP-36, $\mathrm{KCl}\left(\mathrm{P}_{3}\right)$; oil palm empty fruit bunch compost $+25 \%$ urea, SP- $36, \mathrm{KCl}\left(\mathrm{P}_{4}\right)$; oil palm fruit bunch compost $+50 \%$ urea, SP-36, $\mathrm{KCl}\left(\mathrm{P}_{5}\right)$; chicken manure fertilizer $+25 \%$ urea, SP$36, \mathrm{KCl}\left(\mathrm{P}_{6}\right)$; and chicken manure fertilizer $+50 \%$ urea, SP-36, $\mathrm{KCl}\left(\mathrm{P}_{7}\right)$. Research result showed that the combination of organic and inorganic fertilizer gave better result compared to solely organic or inorganic fertilizer. Treatment with the best result for the growth and yield of brown rice was treatment $P_{5}$ (oil palm empty fruit bunch compost $+50 \% N, P, K$ fertilizer), followed by $\mathrm{P}_{7}$ (manure fertilizer $+50 \%$ NPK fertilizer). The highest yield per hectare was treatment $P_{5}$ with 5,49 tonnes.
\end{abstract}

\section{KEY WORDS}

Inorganic fertilizer, organic fertilizer, brown rice.

Rice is a strategic food commodity for it is the staple food of Indonesian people. Rice is also the back bone of food crops subsector development, important for the realization of food security, and gives critical contribution on domestic product national bruto (Sirappa, 2012). The most commonly found rice in Indonesia is white rice, black rice, and brown rice. Rice has various shape and color for both the plant itself and its seeds. In Indonesia, rice with brown seeds (brown rice) does not receive the same level of attention compared to rice with white seeds (white rice), even if it has high level of nutritional content. The largest rice consumption belongs to white rice (Kristamtini and Prayitno, 2009).

Based on its nutritional content, brown rice is very suitable for places with food shortages, especially with people with malnourished status. Rice with high level of protein is beneficial in improving community nutrition. Antocyanin content in brown rice can be a source of antioxidant good for maintaining health. The composition of $100 \mathrm{~g}$ brown rice is 7.5 $\mathrm{g}$ protein, $0.9 \mathrm{~g}$ fat, $77.6 \mathrm{~g}$ carbohydrate, $16 \mathrm{mg}$ calcium, $163 \mathrm{~g}$ phosphorus, $0.3 \mathrm{~g}$ ferrum and $0.21 \mathrm{~g}$ vitamin B1. Brown rice contains high amount of fibre, natural oil, and essential fat beneficial for our body (Indriani et al., 2013).

Brown rice generally has low yield (2-3 tonnes ha-1) and matured slowly for around 5-6 months (Moeljoprawiro et al., 2009). An effort to improve brown rice production is through the addition of fertilizer. Agricultural field outside of Java are mostly red-yellow podzolic land with low fertility and poor nutrient (Notohadiprawiro, 2006), thus additional ameliorant material is required. Ameliorant material commonly used is organic fertilizer and chemical fertilizer. The previous problem can be solved by liming, adding high dosage of chemical fertilizer; however this effort is expensive and generates unfavorable effect on soil in addition to causing environmental problem (Setyorini et al., 2004). Conventional agricultural system with chemical fertilizer and pesticides that gradually gets higher in concentration will leave residues that accumulate into environmental contaminant. Organic compound addition to farm fields is required for $95 \%$ of Indonesian farm fields has less than $1 \%$ of organic 
compound while the minimum limit for organic content suitable for agricultural land is $4 \%$ 5\% (Padmanabha et al., 2014).

To fulfil the nutrition demand for food crops and to reduce chemical fertilizer, utilizing empty oil palm fruit bunch compost and organic compound from leguminosae plant compost as well as using falow rotation system with leguminosae plant as air-nitrogen anchors can be attempted (balasubramanian and Nguimgo, 1993 in Fitriana, 2013). Manure fertilizer and compost are organic soil compound sources. Compost without inorganic fertilizer treatment can restore soil physical properties and soil water content while increasing soil C-organic concentration. Research result by Fitriana (2015) showed that mucuna compost combined with $50 \% \mathrm{~N}, \mathrm{P}, \mathrm{K}$ fertilizer gave the best result on upland rice yield. Other organic fertilizers analyzed were oil palm empty fruit bunch (EFB) compost, which contains nutritions needed by soil and crops. Furthermore, Huda's (2016) research result showed that stringbean compost combined with $50 \% \mathrm{~N}, \mathrm{P}$, and $\mathrm{K}$ fertilizer gave the best result for the number of productive tillers, rice grain weight, and 1000 rice grains weight.

\section{MATERIALS AND METHODS OF RESEARCH}

The research was conducted in experimental farm of Agronomy Department, Agriculture Faculty, Sriwijaya University, Indralaya. The research was carried out for 6 months from May to October 2018. Soil analysis was conducted in Chemistry, Biology, and Soil Fertility Division, Soil Science Department, Faculty of Agriculture, Sriwijaya University, Indralaya Campus, Ogan Ilir, South Sumatra. Crops tissue analysis was conducted in Plant Physiology laboratory, Faculty of Agriculture, Sriwijaya University. This research used randomized block design to test the influence of fertilizer on brown rice yield and soil fertility. The treatments given were:

$\mathrm{P} 1: 100 \% \mathrm{~N}, \mathrm{P}$, and $\mathrm{K}$ fertilizer (200 kg ha ${ }^{-1}$ urea, $75 \mathrm{~kg} \mathrm{ha}^{-1} \mathrm{SP}-36$ and $50 \mathrm{~kg} \mathrm{ha}^{-1} \mathrm{KCl}$ );

P2: stringbean compost $+25 \% \mathrm{~N}, \mathrm{P}, \mathrm{K}$ fertilizer;

P3: stringbean compost $+50 \% \mathrm{~N}, \mathrm{P}, \mathrm{K}$ fertilizer;

P4: oil palm empty fruit bunch compost $+25 \% \mathrm{~N}, \mathrm{P}, \mathrm{K}$ fertilizer;

P5: oil palm empty fruit bunch compost $+50 \% \mathrm{~N}, \mathrm{P}, \mathrm{K}$ fertilizer;

P6: chicken manure fertilizer $+25 \% \mathrm{~N}, \mathrm{P}, \mathrm{K}$ fertilizer;

P7: chicken manure fertilizer $+50 \% \mathrm{~N}, \mathrm{P}, \mathrm{K}$ fertilizer.

Each organic component was 20 tonnes ha ${ }^{-1}$, which were stringbean compost, oil palm empty fruit bunch compost, and chicken manure fertilizer. Brown rice medium for planting was prepared. The research used $20 \mathrm{~kg}$ polybags. Soil was taken from dry land in Agriculture Faculty, Sriwijaya University, Indralaya. The soil was meshed and cleaned off litter before placed inside polybag. Afterwards, composts were added into the polybag according to treatment. Before seeding, the soil was analyzed beforehand to determine the $\mathrm{N}, \mathrm{P}, \mathrm{K}$, and $\mathrm{C}$ contents and soil $\mathrm{pH}$. Brown rice planting was done by putting 5 rice seeds per planting hole. Afterwards, inorganic NPK fertilizers-urea fertilizer, SP-36, and $\mathrm{KCl}$-were given according to treatment. The standard fertilizer dosage was $200 \mathrm{~kg}$ urea per ha, $75 \mathrm{~kg} \mathrm{SP}-36$ per ha and $50 \mathrm{~kg} \mathrm{KCl}$ per ha. A third of urea fertilizer and all of SP-36 and $\mathrm{KCl}$ fertilizer were given at the start of planting. Two third of urea fertilizer was given on the $4^{\text {th }}$ week post planting. Harvest was done if the rice stalk bend from the weight of the grain, rice grain had hardened by palpation, leaves had yellowed, and if the grain had also yellowed. The parameters observed on brown rice were: 1) plant height, 2) number of tillers per clump, 3) number of productive tillers per clump, 4) percentage of filled grain per clump, 5) grain weight per 1000 grains, 6) the number of grains per panicle, 7) the weight of grain per clump, and 8) yield per hectare. Tissue analysis on brown rice was also conducted.

\section{RESULTS AND DISCUSSION}

Rice Growth. The result of analysis of variance showed that organic and inorganic fertilizer combination treatment had significant influence to plant height, number of tillers per clump, number of productive tillers per clump, weight of 1000 grains, weight of grain per 
tillers, and yield per ha and insignificanly influence to grain per tiller percentage and number of grains per panicle.

Plant Height. The result of analysis of variance showed that organic and inorganic fertilizer combination had significant effect to plant height variable. The tallest value was obtained by $\mathrm{P}_{5}$ treatment (oil palm empty fruit bunch compost $(125 \mathrm{~g})+50 \% \mathrm{~N}, \mathrm{P}$, and $\mathrm{K}$ fertilizer) with average height of $70.56 \mathrm{~cm}$ which did not significantly differ with treatment $\mathrm{P} 3$, P4, P6 and P7, but significantly different with P1 and P2 (Table 1).

From Table 1, it can be seen that the tallest crop height was obtained by P5 treatment (oil palm empty fruit bunch compost $(125 \mathrm{~g})+50 \% \mathrm{~N}, \mathrm{P}$, and $\mathrm{K}$ fertilizer) which was significantly differed with P1 treatment $(100 \%$ NPK fertilizer) and P2 stringbean compost + $25 \% \mathrm{~N}, \mathrm{P}, \mathrm{K}$ fertilizer but did not significantly differ with other treatment. P5 treatment which was oil palm empty fruit bunch compost had relatively high nutritional value such as $\mathrm{C}$ organik $30-40 \%$, C/N ratio of $15-20, \mathrm{~N} 2-3.5 \%, \mathrm{P} 0.7-1.2 \%, \mathrm{~K} 3-5 \%, \mathrm{Ca} 2-4 \%$ and $\mathrm{Mg} 1-2 \%$ (Oil Palm Research Center, 2003).

Number of Tillers per Clump. Analysis of variance result showed that organic and inorganic fertilizer combination had very significant effect with the number of tillers per clump. The highest number of tillers was obtained from P7 treatment (manure fertilizer $(125 \mathrm{~g})+$ $50 \% \mathrm{~N}, \mathrm{P}, \mathrm{K}$ fertilizers) with average tillers 47.67 and the lowest number of tillers is $\mathrm{P1}$ treatment $(100 \% \mathrm{~N}, \mathrm{P}$, and $\mathrm{K}$ fertilizer) with average number of tillers 21.11 . P7 treatment had significant difference against all treatments. The number of tillers for every clump can be seen on Table 1.

The highest number of tillers was found in P7 treatment (manure fertilizer $+50 \%$ NPK fertilizer) which is 47.67 , followed by P5 treatment (oil palm empty fruit bunch compost $+50 \%$ NPK fertilizer) which is 43.55, while the lowest number of tillers was found in P1 treatment (100\% NPK fertilizer) with 21.1. Manure fertilizer and oil palm empty fruit bunch compost gave way higher tillers per clump compared to merely NPK fertilizers without organic fertilizer. In this case, organic fertilizer not only added nutritional value to the soil but also improving soil physical and biology characteristic. Treated soil turned friable, something that cannot be achieved by inorganic fertilizer such as NPK fertilizer.

Number of Productive Tillers per Clump. Analysis of variance result showed that organic and inorganic fertilizer combination had significant effect to number of productive tillers per clump. The highest number of productive tiller per clump was found in P7 treatment (manure fertilizer $(125 \mathrm{~g})+50 \%$ NPK fertilizer) with an average 23.67 and the lowest number of productive tillers was found in P1 treatment (100\% NPK fertilizer) with an average 11.89. P7 treatment was significantly different against all treatment. The number of productive tillers for every treatment can be seen in Table 1.

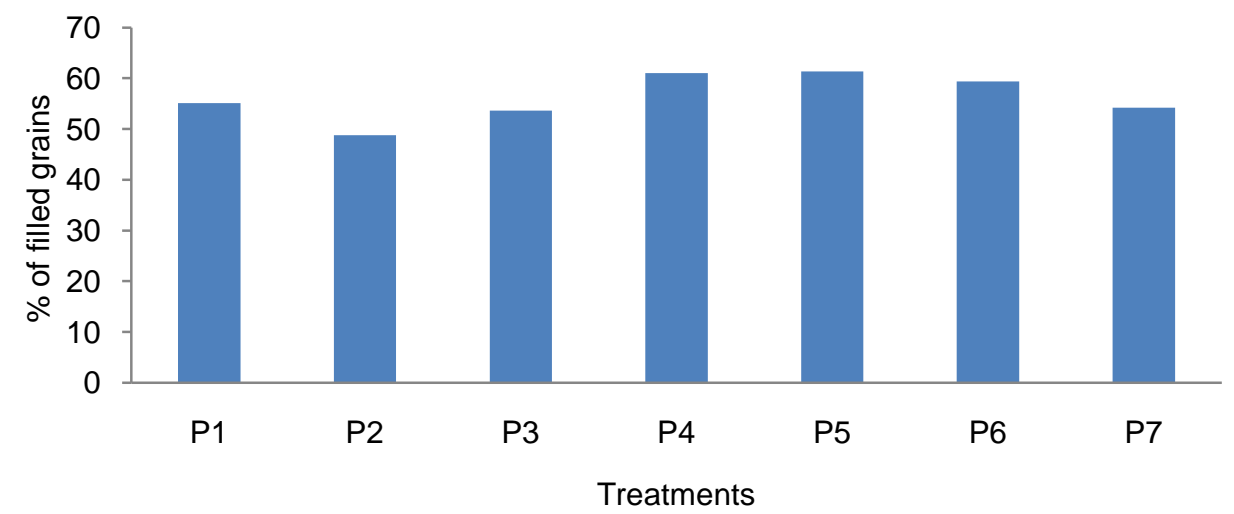

Figure 1 - Combinations of organic and inorganic fertilizer dosages on average percentage of brown rice filled grain per clump

Percentage of Filled Grain per Clump (\%). Analysis of varience result showed that organic and inorganic fertilizer combination had no significant effect against percentage of filled grain per clump. Highest percentage of filled grain was obtained from P5 treatment (oil 
palm empty fruit bunch compost $(125 \mathrm{~g})+50 \%$ NPK fertilizer) with average 61.34 and the lowest percentage of filled grain per clump was obtained from P2 (stringbean compost (125 g) $+25 \%$ NPK fertilizer) with the average 48.75 . Percentage of filled grain per clump can be seen on Figure 1.

Weight of 1000 Grains (g). Analysis of varience result showed that organic and inorganic fertilizer had significant effect on the weight of 1000 grains. The highest weight of 1000 grains was obtained from P3 treatment (stringbeans compost $(125 \mathrm{~g})+50 \%$ NPK fertilizer) with average $29.83 \mathrm{~g}$ and the lowest weight of 1000 grains was obtained from P6 treatment (manure fertilizer $(125 \mathrm{~g})+25 \%$ NPK fertilizer) with average 21.40. P3 treatment was not significantly different with $\mathrm{P} 2$ treatment but significantly diffirent with $\mathrm{P} 1, \mathrm{P} 4, \mathrm{P} 5, \mathrm{P} 6$, and P7 (Table 1).

Weight of Filled Grain per Clump. Analysis of varience result showed that organic and inorganic fertilizer combination had significant effect on the weight of filled grain per clump. The highest weight of filled grain was obtained from P5 treatment (Oil palm empty fruit bunch compost $(125 \mathrm{~g})+50 \%$ NPK fertilizer) with average value $34.28 \mathrm{~g}$ and the lowest weight for filled grain per clump was found in P1 treatment (100\% NPK fertilizer) with average $14.77 \mathrm{~g}$. P5 treatment is significantly different against every treatment (Table 1).

Number of Grain per Panicle. Analysis of variance result showed that organic and inorganic fertilizer combination did not have significant effect to the number of grains per panicle. The highest number of grains per panicle was obtained from P4 treatment (oil palm empty fruit bunch compost $(125 \mathrm{~g})+25 \%$ NPK fertilizer) with an average 113.15 and the lowest number of grains per panicle was obtained from P2 (stringbean compost $125 \mathrm{~g}+25 \%$ NPK fertilizer) with the average 90.87 . The number of grain per panicle can be seen from Figure 2.

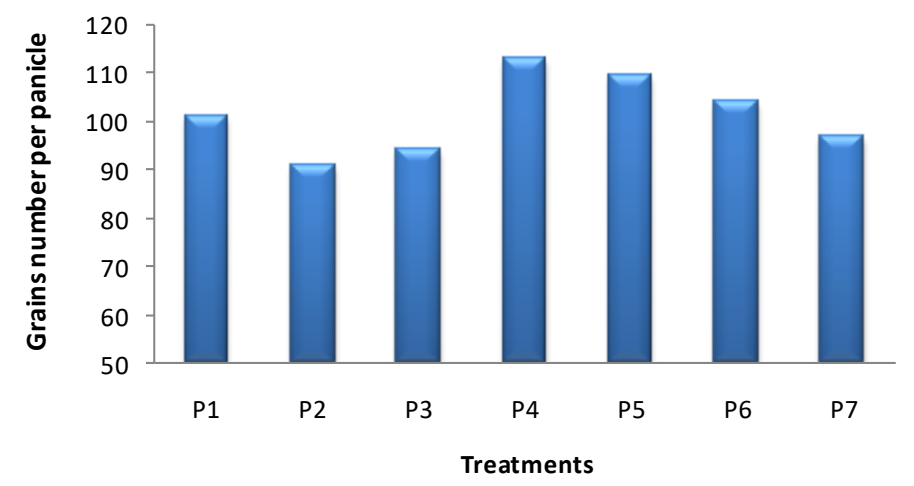

Figure 2 - Combinations of organic and inorganic fertilizer dosages on average percentage of brown rice grains number per panicle

Yield per Hectare. Analysis of variance result showed that organic and inorganic fertilizer combination had significant effect to yield per hectare. The highest yield was obtained from P5, which was 5.49 tonnes, which was significantly different with P1, P2, P3, P6, and P7, and not significantly different with P4. The lowest yield was obtained from P1 with 2.36 tonnes (100\% NPK fertilizer). The result can be seen from Table 1.

\section{DISCUSSION OF RESULTS}

Analysis of variance result showed that organic and inorganic fertilizer combination significantly affected crop height, number of tillers per clump, number of productive tillers per clump, weight of 1000 grains, and weight of filled grain per clump, but did not give significant effect to percentage of filled grain per clump and the number of grains per panicle. For crop height, percentage of filled grain, weight of filled grain, and highest yield per ha, the highest value belongs to P5 treatment (oil palm empty fruit bunch compost $+50 \%$ NPK fertilizer). This was assumed to occur because the nutritional value in oil palm empty fruit bunch was 
very high. Macro nutrition contained in POEFB are as follow: C 35\%, K 5,53\%, N 2,32\%, Ca 1,146\%, Mg 0,95\% and P 1,146\% (Oil palm Research Center, 2003). Oil palm empty fruit bunch compost fertilizer was formulated in granule form, including slow-releasing fertilizer so that it could stand long period of time. Based on brown rice tissue analysis, highest $\mathrm{K}$ nutrition value was obtained from oil palm empty fruit bunch. Based on Purnamayani (2014), high $\mathrm{K}$ nutritional content in oil palm empty fruit bunch compost fertilizer might increase survival against drought and disease. $\mathrm{K}$ nutrition in oil palm empty fruit bunch compost is not easily washed for they are trapped on compost colloid humus and thus can still be available until harvest because of its slow release properties. In a research by lqbal et al. (2016), stated that combination of oil palm empty fruit bunch compost fertilizer 7.5 tonnes/ha with $\mathrm{P}_{2} \mathrm{O}_{5} 46.575 \mathrm{~kg} / \mathrm{ha}$ can give highest yield for upland brown rice.

Organic and inorganic fertilizer combination treatment significantly affected number of tillers and productive tillers per clump. The highest number of tillers and productive tillers per clump was obtained in P7 treatment (manure fertilizer $(125 \mathrm{~g})+50 \%$ NPK fertilizer) with the average 47.67 and 23.67. The use of (chicken) manure is better than other kind of manure where every tonne of chicken manure has $65.8 \mathrm{~kg} \mathrm{~N}, 13.7 \mathrm{~kg} \mathrm{P}$ and $12.8 \mathrm{~kg} \mathrm{~K}$ whereas the same amount of cow manure only has $22 \mathrm{~kg} \mathrm{~N}, 2.6 \mathrm{~kg} \mathrm{P}$, and $13.7 \mathrm{~kg} \mathrm{~K}$ (Nurhayati, 1988). Several research on application of chicken manure fertilizer always gave the best plant response in the first season. This happened for chicken manure fertilizer is relatively fast to decompose with adequate nutrition value compared to other fertilizer in the same unit (Widowati et al, 2005). The highest number of tiller was obtained from P7 (chicken manure + $50 \%$ NPK fertilizer) which was 47.67 followed by P5 (oil palm empty fruit bunch compost + $50 \%$ NPK fertilizer) with 43.55, while the lowest number of tillers was obtained in P1 treatment (100\% NPK fertilizer) with 21.22. Chicken manure fertilizer and oil palm empty fruit bunch compost reached way higher number of tillers compared with only NPK fertilizer without organic fertilizer. In this case, organic fertilizer not only added nutrition but also improve soil physical and biological properties by making it more friable, something that inorganic fertilizer such as NPK fertilizer cannot provide.

Table 1. Combinations of organic and inorganic fertilizers on all observed parameters

\begin{tabular}{crrrrrrrr}
\hline \multirow{2}{*}{ Treatment } & \multicolumn{8}{c}{ Parameter } \\
\cline { 2 - 9 } & 1 & \multicolumn{1}{c}{2} & \multicolumn{1}{c}{3} & \multicolumn{1}{c}{5} & \multicolumn{1}{c}{6} & \multicolumn{1}{c}{7} & \multicolumn{1}{c}{8} \\
\hline P1 & $59.33 \mathrm{a}$ & $21.11 \mathrm{a}$ & $11.89 \mathrm{a}$ & 55.09 & $22.60 \mathrm{a}$ & $14.77 \mathrm{a}$ & 101.06 & $2.36 \mathrm{a}$ \\
P2 & $66.44 \mathrm{~b}$ & $36.78 \mathrm{~b}$ & $18.44 \mathrm{~b}$ & 48.74 & $25.00 \mathrm{ab}$ & $18.84 \mathrm{a}$ & 90.87 & $3.02 \mathrm{a}$ \\
P3 & $69.00 \mathrm{bc}$ & $40.33 \mathrm{bc}$ & $21.22 \mathrm{bc}$ & 53.66 & $29.83 \mathrm{~b}$ & $26.23 \mathrm{~b}$ & 94.41 & $4.20 \mathrm{~b}$ \\
P4 & $67.00 \mathrm{bc}$ & $37.22 \mathrm{~b}$ & $19.56 \mathrm{bc}$ & 61.01 & $21.67 \mathrm{a}$ & $29.88 \mathrm{ab}$ & 113.15 & $4.78 \mathrm{bc}$ \\
P5 & $70.56 \mathrm{c}$ & $43.55 \mathrm{~cd}$ & $23.11 \mathrm{c}$ & 61.34 & $22.77 \mathrm{a}$ & $34.28 \mathrm{c}$ & 109.58 & $5.49 \mathrm{c}$ \\
P6 & $69.33 \mathrm{bc}$ & $37.67 \mathrm{bc}$ & $20.56 \mathrm{bc}$ & 53.36 & $21.40 \mathrm{a}$ & $28.08 \mathrm{~b}$ & 104.27 & $4.49 \mathrm{~b}$ \\
P7 & $70.00 \mathrm{c}$ & $47.67 \mathrm{~d}$ & $23.67 \mathrm{~cd}$ & 54.20 & $23.33 \mathrm{a}$ & $27.28 \mathrm{~b}$ & 96.71 & $4.36 \mathrm{~b}$ \\
\hline LSD 0.05 & 3.63 & 6.02 & 3.72 & tn & 4.88 & 4.97 & tn & 0.80 \\
\hline
\end{tabular}

Notes:

P1: $100 \% \mathrm{~N}, P$, and $\mathrm{K}$ fertilizer $\left(200 \mathrm{~kg} \mathrm{ha}^{-1}\right.$ urea, $75 \mathrm{~kg} \mathrm{ha}^{-1} \mathrm{SP}-36$ and $\left.50 \mathrm{~kg} \mathrm{ha}^{-1} \mathrm{KCl}\right)$;

$P 2$ : stringbean compost $+25 \% N, P, K$ fertilizer;

$P 3$ : stringbean compost $+50 \% \mathrm{~N}, P, K$ fertilizer;

$P 4$ : oil palm empty fruit bunch compost $+25 \% N, P, K$ fertilizer;

P5: oil palm empty fruit bunch compost $+50 \% \mathrm{~N}, P, K$ fertilizer;

P6: chicken manure fertilizer $+25 \% N, P, K$ fertilizer;

P7: chicken manure fertilizer $+50 \% N, P, K$ fertilizer;

1) plant height, 2) number of tillers per clump, 3) number of productive tillers per clump, 4) percentage of filled grain per clump, 5) grain weight per 1000 grains, 6) weight of filled grain per clump 7) number of grains per panicle, and 8) yield per hectare.

In 1000 grains weight variable, the highest weight was obtained from P3 treatment (stringbean compost $(125 \mathrm{~g})+50 \%$ NPK fertilizer) with the average of 29.83. P3 treatment has high 1000 grain weight and big grain size compared to other treatment. Stringbean plant is a leguminose with high content of $\mathrm{N}$, with its components consist of $\mathrm{N}\left(65 \mathrm{Kg} \mathrm{ha}^{-1}\right), \mathrm{P}(6 \mathrm{Kg}$ $\left.\mathrm{ha}^{-1}\right), \mathrm{K}\left(33 \mathrm{Kg} \mathrm{ha}^{-1}\right), \mathrm{Ca}\left(23 \mathrm{Kg} \mathrm{ha}^{-1}\right), \mathrm{Mg}\left(16 \mathrm{Kg} \mathrm{ha}^{-1}\right)$, and S (6 Kg ha-1) (Saraswati, 2006). 


\section{CONCLUSION}

Conclusions proposed from this research is that the best treatment for the growth and yield of brown rice is P5 treatment (oil palm empty fruit bunch compost $+50 \%$ NPK fertilizer) followed by P7 (manure fertilizer $+50 \%$ NPK fertilizer). The highest yield per hectare was obtained from P5 with 5.49 tonnes. Suggestions that could be given based on this research is to use organic fertilizer such as manure fertilizer and Leguminosae compost combined with NPK fertilizer on $50 \%$ dosage for brown rice planting.

\section{REFERENCES}

1. Fitriana, M. 2013. The Application of Organic Materials and NPK Fertilizer on Weed Growth and Corn Yield in Dryland Corn Rotation Farm. Faculty of Agriculture, Sriwijaya University. Dissertation (unpublished). (in Indonesian).

2. Fitriana, M. and Yakup. 2015. The Application of Leguminosae Compost to Increase Upland Rice Production for Food Security Development. Report of Competitive Research, Sriwijaya University. (in Indonesian).

3. Indriani, F., Nurhidayah, and A.Suyanto. 2013. Physical, Chemical and Organoleptic Characteristics of Brown Rice Flour based on the Variations of Drying Duration. Jurnal Pangan and Gizi 4(8): 27-34. (in Indonesian).

4. Iqbal, M. and Zuhry, E. 2016. The Application of Oil Palm Empty Fruit Bunch Compost and $\mathrm{P}_{2} \mathrm{O}_{5}$ on Growth and Yield of Brown Rice. Online Student Journal of Agriculture Faculty, Riau University 3(2): 1-15. (in Indonesian).

5. Kristamtini and Prajitno A.L. K.S. 2009. The Characteristics of Brown Rice Plant Superior Local Variety Gunung Kidul. Jurnal ilmu pertanian 5(1). (in Indonesian).

6. Moeljoprawiro S., Husni K., Hermanto, Ida N O., and Agus N. 2009. Saving Brown Rice Germplasms. Warta Plasma Nutfah Indonesia No.1. (in Indonesian).

7. Notohadiprawiro, T. 2006. Dryland Farming in Indonesia: Potency, Prospect, Constraint, and Development. http://soil.faperta.ugm.ac.id/tj/1981/1989\% 20pert\%20l.pdf. Accessed on September 30, 2013. (in Indonesian).

8. Nurhayati. 1988. Fertilizer and Fertilizing. Agriculture Faculty, Andalas University. (in Indonesian).

9. Oil Palm Research Center. 2003. The Production of Oil Palm Empty Fruit Bunch Compost. PT. Perkebunan Nusantara. Medan. (in Indonesian).

10. Padmanabha I.G., I Dewa M.A., and I Nyoman D. 2014. The Application of Organic and Inorganic Fertilizer Dosages on Rice (Oryza sativa L.) Yield and Soil Chemical Properties of Inceptisol in Tabanan. E-Jurnal Agroekoteknologi Tropika 3(1):2301-6515. (in Indonesian).

11. Saraswati. 2006. Organic Fertilizer and Green Fertilizer. Hayati. Research and Development Center of Agricultural Resources, Agricultural Research and Development Center, Bogor. (in Indonesian).

12. Setyorini, D., L.R. Widowati and S. Rochayati. 2004. Nutrient Management Technology of Intensified Ricefield. In F. Agus, A. Adimihardja, A.M. Fagi and W. Hartatik (Eds.). Ricefield and Its Management Technology. Soil and Agroclimate Center of Research and Development, Bogor. 137-167. (in Indonesian).

13. Sirappa, M.P. 2012. Strategy to Increase Rice Production. Agricultural Technology Study Center, West Sulawesi. (in Indonesian).

14. Widowati, L.R., Sriwidati, U. Jaenudin and W. Hartatik. 2005. The Application of Organic Fertilizer Enriched with Minerals and Green Fertilizer on Soil Properties, Nutrient Absorption, and Yield of Organic Vegetables. Report of Agribusiness Development Research Project, Soil Research Center. 2005 (unpublised). (in Indonesian). 